\title{
Medication review in inpatients at cardiology clinic Prehodnotenie terapie u hospitalizovaných pacientov na kardiologickej klinike
}

\author{
${ }^{1}$ Univerzita Komenského v Bratislave, Farmaceutická fakulta, \\ Katedra farmakológie a toxikológie \\ ${ }^{2}$ Fakultná nemocnica Nitra, Kardiologická klinika \\ ${ }^{3}$ Fakultná nemocnica Nitra, Klinika novorodencov, detí a dorastu
}

${ }^{1}$ Comenius University in Bratislava, Faculty of Pharmacy,

/ Department of Pharmacology and Toxicology

${ }^{2}$ Teaching Hospital Nitra, Cardiology Clinic

${ }^{3}$ Teaching Hospital Nitra, Department of Neonatology

Received 24 October 2014, accepted 13 March 2015

Abstract This study deals with effect of hospital pharmacist on solving drug-related problems (DRP) in inpatients. The study was carried out as a prospective 5-week study at the Cardiology Clinic, Teaching Hospital, Nitra. The study group included 73 inpatients. Pharmacotherapy of each patient was analysed for DRP within 24-48 h after admission. Information on patients was collected from electronic database, medical reports, communication with attending doctors and ward rounds. Patients'age, medical history, diagnoses, medication prescribed during hospitalisation and laboratory test results were assessed for further pharmacotherapy rationalisation. Pharmaceutical Care Network Europe (PCNE) classification scheme for DRP V6.2 was used to characterise DRP. There were 36 DRP identified in 37\% inpatients $(n=27)$. The most frequent causes of DRP were dose-related $(n=13 ; 26 \%)$ and use

Slovak Táto práca poukazuje na možnosti farmaceuta pri identifikovaní a riešení farmakoterapeutických problémov (DRP) u abstract hospitalizovaných pacientov. Sledovaný súbor tvorilo 73 pacientov, ktorí boli hospitalizovaní na Kardiologickej klinike. U každého pacienta zaradeného do štúdie sa prehodnotila terapia do 24-48 hodín od prijatia k hospitalizácii. Informácie o pacientoch sme čerpali z elektronickej databázy, chorobopisov, osobnej konzultácie s lekárom a lekárskych vizít. Sledovanými údajmi pri racionalizácii terapie bol vek pacienta, lieková anamnéza, diagnózy, ordinovaná terapia a laboratórne parametre. Identifikáciu a riešenie DRP sme vykonávali podla PCNE klasifikácie V6.2. V 37\% $(n=27)$ chorobopisov sme identifikovali 36 DRP. Najčastejšou príčinou DRP bola vel'kost' dávky ( $n=13 ; 26 \%)$ a výber nevhodného alebo kontraindikovaného liečiva ( $n=11 ; 22 \%)$. Ciel'om tejto

Keywords medication reconciliation-inpatient - PCNE-DRP-clinical pharmacist

Klúčové prehodnotenie medikácie - hospitalizovaný pacient-PCNE-DRP-klinický farmaceut

slová:

\section{INTRODUCTION}

Ageing of population, higher occurrence of chronic diseases, changing morbidity-mortality ratio and introduction of new drugs led to permanent growth of healthcare expenditures. Geriatric patients, especially, suffer from polymorbidity; they visit numerous healthcare specialists and consume huge amount of medicines (Bushardt et al. 2008). Insufficient computerisation in healthcare system and patients' poor awareness of their medicines bring about duplicate prescription of the same drug and inappropriate or even contraindicated drugs (Riechelmann et al. 2007). Such a therapy fails or adverse drug events (ADE) appear. The patient is prescribed another new medication, problem snowballs and the situation keeps happening in a vicious circle (Shi et al. 2008).

In 1994, Pharmaceutical Care Network Europe (PCNE) was established to support the quality of provided pharmaceutical care within Europe. To improve safety in healthcare, the association creates guidelines and so-called Classification for Drug Related Problems, which enables to describe drugrelated problems (DRP) uniformly and serves as a process indicator in experimental studies (Classification for Drug Related Problems, 2010).

Admission of patient to hospital, transfers within the hospital, and discharge from the hospital are considered to be the most critical moments for occurrence of medication errors. Medication reconciliation during these moments considerably eliminates DRP. This is a field for clinical and hospital pharmacists, as they have access to patients' data on medication and health progress and possibility to communicate with treating doctors. Being involved in therapy management, pharmacists are able to intercept both existing and potential errors and so decrease the number of $A D E$,

*E-mail:kovacova@fpharm.uniba.sk

(c) Acta Facultatis Pharmaceuticae Universitatis Comenianae 
shorten the length of hospital stay, and save the costs (World Health Organization [WHO]: High 5's; Campbell et al. 2013).

The common activities of clinical pharmacists include medication review of therapy at patient admission and during the whole period of hospitalisation, providing pharmacokinetic service (therapeutic drug monitoring [TDM] and interpreting the results), educating patients and healthcare staff. Such a complex model of pharmaceutical care, recommended by the WHO, is well established in many countries worldwide and proves its efficacy.

In Slovakia, the model is being introduced, lately. Therefore, the aim of our study is to introduce the medication reconciliation service at the cardiology clinic and characterise the prevalence and nature of DRP.

\section{EXPERIMENTAL PART}

The study was designed as a 5-week (October and December 2013) prospective study at the Cardiology Clinic, Teaching Hospital, Nitra. All data on the patients were collected from the electronic database of the hospital, medical reports, ward rounds and consultations with doctors. Age, gender, medication prior to admission, diagnoses from previous and last examinations, allergies, daily medication during hospitalisation, and laboratory results were taken into consideration. Abnormalities in laboratory results were analysed for possible relation to drug interactions, ADE and use of inappropriate drug. Valid Summaries of Product Characteristics (SPC) approved by State Institute for Drug Control were used as primary sources of information (www.sukl.sk). Appropriateness of each medication in the patient's medication record was assessed for indications, contraindications, doses and dose regimens, overuse and undesirable effects. Slovak guidelines for rational pharmacotherapy published by Ministry of Health of Slovak Republic (Metodické listy racionálnej farmakoterapie), SCOPUS database and guidelines published by other scientific associations were used as additional sources of information. As the Slovak versions of SPC only rarely contain information on clinical severity (risk rating) of drug interactions, the detailed description was obtained from Lexicomp ${ }^{\circledR}$ database and Drug Interaction Facts (Tatro DS, 2011). In both of them, the clinical significance rating of interactions is stratified into five grades. Moreover, recommendation for further management of interaction is proposed. When reviewing the medication, all grades of interactions were taken into consideration, but just the two highest risk ratings were subjects for instant consultation with attending doctor.

Pharmacotherapies of the included patients were analysed by one pharmacist within 24-48 $\mathrm{h}$ after admission to the hospital. This time frame is suggested by WHO, as it enables an early identification and elimination of DRP, reduces polypharmacy and risk of $A D E$, interactions and duplications (WHO: High 5`s). The first step prior to analysis itself was to assess the completeness of medical report at admission. If available, previous medical reports and back records from the hospital database were used to cover missing and ambiguous data. The next step was to review the medication taken prior to admission (i.e. home medication or medication prior to transfer) in relation to diagnoses and medication prescribed during current hospitalisation at the clinic. The pharmacist then carried out medication review during working days (2-3 times per week) up to the end of hospitalisation. Multidisciplinary ward rounds took place 2 times per week: on Mondays and Thursdays at womenss ward; on Tuesdays and Fridays at menss ward. Any identified DRP (potential or manifest) were discussed with attending doctor and a proposal for medication modification was offered.

The identified DRP, their causes, the interventions and outcomes were characterised according to PCNE classification V6.2; last updated in 2010. One Problem (P) can have more Causes (C), can lead to more Interventions (I), but can only lead to one Outcome (O). The results of our analysis were evaluated using descriptive statistics by Microsoft Excel version 2013. The study was approved by Ethic Committee of Teaching Hospital, Nitra.

\section{RESULTS}

During the study period, 73 medication records (52\% women; mean age 71 years, range 37-99 years) were analysed. The patients were prescribed total amount of 795 medications (850 drugs) during the hospitalisation, ranging from 2 to 28 medications per patient.

At least one DRP was found in 27 (37\%) medication records; together 36 DRP were identified (1.3 DRP per patient). The patients with identified DRP included 14 (52\%) men of the age 46-93 years (mean age 71 years). All the potential and manifest problems that were found in the study group are listed in Table 1.

The most frequent problems were potential or manifest toxic ADE ( $n=18 ; 50 \%)$ and non-allergic ADE ( $n=10 ; 28 \%)$. They were caused by combinations of drugs leading to pharmacokinetic or pharmacodynamic interactions or by using contraindicated drugs. Risk or manifestation of toxic ADE were noticed mainly in patients using drugs with narrow therapeutic index. These drugs, such as digoxin, theophylline or gentamicin, require monitoring of plasma concentrations. Teaching Hospital, Nitra, has established Department of Clinical Pharmacology with one clinical pharmacist carrying out TDM of these drugs for more than 20 years. Therefore, missing TDM in patients using such drugs was considered as DRP.

Another risk group was drugs requiring dose adjustment in patients with chronic decreased kidney functions. In our study, doses of amoxicillin/clavulanate, amantadine, and clarithromycin were potential subjects for adjustment.

Drug dose too high was the most frequent cause of drugrelated problems ( $n=13 ; 26 \%$ ) (Table 2 ). It was found mainly in patients with renal insufficiency. We found 11 cases (22\%) 
Table 1. Identified problems according to Pharmaceutical Care Network Europe classification

\begin{tabular}{|c|c|c|}
\hline $\begin{array}{l}\text { Code } \\
\text { V6.2 }\end{array}$ & Problem & $\begin{array}{c}\text { Total } \\
(n=36)\end{array}$ \\
\hline P1.1 & $\begin{array}{l}\text { No effect of drug treatment/ } \\
\text { therapy failure }\end{array}$ & 2 \\
\hline P1.2 & $\begin{array}{c}\text { Effect of drug treatment not } \\
\text { optimal }\end{array}$ & 5 \\
\hline P2.1 & $\begin{array}{l}\text { Adverse drug event (non- } \\
\text { allergic) }\end{array}$ & 10 \\
\hline P2.3 & Toxic adverse drug-event & 18 \\
\hline P3.2 & Unnecessary drug-treatment & 1 \\
\hline
\end{tabular}

Table 2. Identified causes of DRP according to Pharmaceutical Care Network Europe classification

\begin{tabular}{|c|c|c|}
\hline $\begin{array}{c}\text { Code } \\
\text { V6.2 }\end{array}$ & Cause & $\begin{array}{c}\text { Total } \\
\text { (n= 50) }\end{array}$ \\
\hline C1.1 & $\begin{array}{c}\text { Inappropriate drug (incl. } \\
\text { contraindicated) }\end{array}$ & 4 \\
\hline C1.3 & $\begin{array}{c}\text { Inappropriate combination of drugs, } \\
\text { or drugs and food }\end{array}$ & 11 \\
\hline C1.4 & $\begin{array}{c}\text { Inappropriate duplication of } \\
\text { therapeutic group or active ingredient }\end{array}$ & 3 \\
\hline C1.7 & More cost-effective drug available & 3 \\
\hline C3.2 & Drug dose too high & 13 \\
\hline C3.5 & No therapeutic drug monitoring & 5 \\
\hline C3.6 & $\begin{array}{c}\text { Pharmacokinetic problem requiring } \\
\text { dose adjustment }\end{array}$ & 7 \\
\hline C5.1 & $\begin{array}{c}\text { Inappropriate timing of administration } \\
\text { and/or dosing intervals }\end{array}$ & 3 \\
\hline C8.1 & Other cause & 1 \\
\hline
\end{tabular}

DRP: Drug-related problems

of inappropriate combination of drugs leading to serious pharmacokinetic or pharmacodynamic interactions.

Each DRP was consulted personally with attending doctor. In addition, the doctor was given a brief written analysis of DRP (e.g. mechanism of interaction and its significance grade) and suggestion for treatment modification.

Totally, 65 interventions for 36 DRP were suggested (Table 3). Out of them, 24 (67\%) were accepted and implemented and $2(6 \%)$ were refused. In 10 cases (28\%), only recommendation to monitor particular parameters more intensively was given. In these cases, no further interventions of the pharmacist were needed (Table 4).

\section{DISCUSSION}

Published studies examining effectiveness of clinical pharmacists reviewing medication differ in setting (hospital, community pharmacy), study design (prospective,
Table 3. Proposed interventions according to Pharmaceutical Care Network Europe classification

\begin{tabular}{|c|c|c|}
\hline $\begin{array}{c}\text { Code } \\
\text { V6.2 }\end{array}$ & Intervention & $\begin{array}{c}\text { Total } \\
\text { (n= 65) }\end{array}$ \\
\hline I1.1 & Prescriber informed only & 10 \\
\hline I1.2 & Prescriber asked for information & 2 \\
\hline I1.3 & $\begin{array}{c}\text { Intervention proposed, approved by } \\
\text { prescriber }\end{array}$ & 24 \\
\hline I1.4 & $\begin{array}{c}\text { Intervention proposed, not approved } \\
\text { by prescriber }\end{array}$ & 2 \\
\hline I1.5 & Intervention proposed, outcome & 1 \\
\hline I3.1 & Drug changed to .... & 11 \\
\hline I3.2 & Dosage changed to .... & 9 \\
\hline I3.4 & Instructions for use changed to .... & 1 \\
\hline I3.5 & Drug stopped & 5 \\
\hline
\end{tabular}

Table 4. Outcomes according to Pharmaceutical Care Network Europe classification

\begin{tabular}{|c|c|c|}
\hline $\begin{array}{c}\text { Code } \\
\text { V6.2 }\end{array}$ & Outcome & $\begin{array}{c}\text { Total } \\
(\mathbf{n}=\mathbf{3 6})\end{array}$ \\
\hline O1.0 & Problem totally solved & 25 \\
\hline O2.0 & Problem partially solved & 1 \\
\hline O3.4 & $\begin{array}{c}\text { No need or possibility to solve } \\
\text { problem }\end{array}$ & 10 \\
\hline
\end{tabular}

retrospective), method and range of activities of pharmacists. In hospitals, clinical pharmacists are able to identify at least one DRP in $20-99 \%$ of inpatients. Access to all available patient information and following the patient throughout hospitalisation ensure higher labour efficiency and contribution to rational pharmacotherapy. Direct communication with attending doctors brings higher number of implemented changes than writing notes to medical report only (implementation 69-99\% against 39-70\% of suggested changes) (Buck et al. 2007; Vand \& Hermansen, 2012; Nielsen et al. 2013). In our study, both methods written DRP analysis for doctors and personal consultation with them - were applied. Personal communication with doctor helped us better understand strategy of therapy and eliminate "misidentification" of DRP. The doctors accepted and implemented $67 \%$ of suggested changes proposed by the pharmacist. The pharmacist was able to identify at least one DRP in $37 \%$ of medication records. There is a probability that the number of identified DRP would have been slightly different (probably higher) if the medication records had been reconciled independently by more than one reviewer. In some cases, it was impossible to compare home medication with hospital prescription, as the information on home medication was missing or incomplete. The reason was 
that some patients did not know their medication and the information was not recorded in the hospital database.

Depending on number of medicines taken, incidence of interactions with moderate or high clinical significance is about $13-82 \%$. The incidence is twice as much frequent in older people than in younger ones, as they suffer from more diseases, take more medicines, and undergo pathophysiological changes due to ageing. When searching for detailed information on drug-drug interactions, databases such as DrugDigest ${ }^{\oplus}$, Drugs ${ }^{\oplus}$, Micromedex ${ }^{\circledast}$, Medscape ${ }^{\circledast}$, Stockley's Drug Interactions proved to be useful, as the information in SPC are often insufficient or even missing (Bergk et al. 2005). Therefore, we used SPC along with Lexicomp ${ }^{\otimes}$ and Drug interaction facts (Tatro 2011). However, the risk ratings of some interactions in these databases differed substantially. A similar situation applied to dose recommendations in chronic renal insufficiency by various sources.

Numerous prospective and retrospective studies proved that periodical medication review can reveal and avoid from most of ADE. According to Agency for Healthcare Research \& Quality (AHRQ), 28-95\% of ADE are preventable (AHRQ, 2001). In our study group, potential or manifest toxic ADE were identified in $25 \%$ of analyzed records. Majority of them were caused by drugs widely used in cardiology, that is digoxin, statins, theophylline, and warfarin. These drugs (except statins) have narrow therapeutic index and high interaction potential, which strongly increases the risk of toxicities.

To increase patient's compliance, clinical pharmacists are widely involved in interviewing patients about additional information and in counselling about changes in their therapy. Currently, Slovak healthcare system experiences a critical lack of clinical pharmacists serving in hospitals, and they have quite a wide range of activities. Therefore, completing missing medication data at admission or educating the patient at discharge is virtually impossible. Such activities belong to daily routine of clinical pharmacists worldwide but their realiszation requires adequate personal staffing and task management (Burns \& Still, 2003). In our study, all patient and medication data were obtained from electronic database, medication records, and consultation with doctors. The patients were not interviewed by pharmacist.

\section{CONCLUSION}

Medicine safety is fundamental principle of pharmacotherapy in order to prevent medical disasters. Despite the strict legislation, the everyday medical practice is unable to avoid problems related to drugs: from wrong prescription to misuse by patient. Clinical pharmacists all around the world improve safety of provided therapy, fulfill the concept of evidencebased medicine and increase the cost-effectiveness. Our results confirm the importance of medication review in hospitalised patients and revealed the most frequent types of DRP.

\section{ACKNOWLEDGEMENTS}

This study was realiszed with financial support by Pharmaceutical Faculty Comenius University FaF UK/7/2013. The authors would like to thank attending doctors of Cardiology Clinic of Teaching Hospital, Nitra, for consultations and access to medication records of their patients.

\section{References}

[1] AHRQ. Reducing and preventing adverse drug events to decrease hospital costs. (http://www.ahrq.gov/research/findings/ factsheets/errors-safety/aderia/index.html\#Introduction). Accessed February 10, 2013.

[2] Bergk $V$ et al. Information deficits in the summary of product characteristics preclude an optimal management of drug interactions: A comparison with the evidence from the literature. Eur J Clin Pharmacol. 2005; 61(5-6): 327-335.

[3] Buck TC, Brandstrup L, Brandslund I, Kampmann JP. The effects of introducing a clinical pharmacist on orthopaedic wards in Denmark. Pharm World Sci. 2007; 29(1): 12-18.

[4] Burns N, Still E. Pharmaceutical care - A model for elderly patients. Hosp Pharm. 2003; 10(6): 266-268.

[5] Bushardt RL, Massey EB, Simpson TW, Ariail JC, Simpson KN. Polypharmacy: Misleading, but manageable. Clin Interv Aging. 2008; 3(2): 383-389.

[6] Campbell G, Auyeung V, McRobbie D. Clinical pharmacy services in a London hospital, have they changed? Int J Clin Pharm. 2013; 35: 688-691.
[7] Classification for Drug related problems, 2010. (http://pcne. org/sig/drp/documents/PCNE\%20classification\%20V6-2.pdf). Accessed January, 12, 2014.

[8] Metodické listy racionálnej farmakoterapie. (http://www.health. gov.sk/?metodicke-listy-racionalnej-farmakoterapie). Accessed December 3, 2013.

[9] Nielsen TRH, Andersen SE, Rasmussen M, honore PH.Clinical pharmacist service in the acute ward. Int J Clin Pharm. 2013. 35(6):1137-1151.

[10] Riechelman RP, Tannock IF, Wang L, Saad ED, Taback NA, Krzyzanowska MK. Potential Drug Interactions and Duplicate Prescriptions Among Cancer Patients. Journal of National Cancer Institute. 2007; 99(8): 592-600.

[11] Shi S, Morike K, Klotz U. The clinical implications of ageing for rational drug therapy. Eur J Clin Pharmacol. 2008; 64:183-199.

[12] Štátny ústav pre kontrolu liečiv: (www.sukl.sk). Accessed December 4, 2013

[13] Tatro DS. Drug interaction facts 2012. The Authority on Drug Interactions. Facts \& Comparisons. Missouri: Lippincott Williams \& Wilkins, 2011. 
[14] Vand S, Hermansen I. How can clinical pharmacy profession be used at the emergency wards? SJTREM, 2012; 20 (2 suppl): 25.

[15] World Health Organization: High 5`s: Action on patient safety. (http://www.safetyandquality.gov.au/our-work/medicationsafety/medication-reconciliation/who-high-5s-medicationreconciliation-program/). Accessed January 6, 2014

[16] World Health Organization: High 5`s: Assuring medication accuracy at transitions in care: Medication reconciliation. (http:// www.who.int/patientsafety/implementation/solutions/high5s/ ps_med_rec_fs_Mar_2011.pdf?ua=1). Accessed January 3, 2014. 